\title{
PROGRAM STRATA 3 TEKNOLOGI PENDIDIKAN DITINJAU DARI PENDIDIKAN HUMANIORA
}

(Studi Kasus Pada Program Pasca Sarjana Tahun 1997-1999)

Oleh: Nurdin Ibrahim *

\section{Abstrak}

Teknologi Pendidikan merupakan program tertua di Pasca Sarjana UNJ. Sebagai salah satu program Pasca Sarjana hendaknya dapat menghasilkan atau meluluskan Master dan Doktor yang mampu menerapkan, mengembangkan dan menciptakan serta mengkaji berbagai model dan media pembelajaran untuk memecahkan masalah belajar manusia. Kegiatan penerapan, pengembangan dan penciptaan tersebut hendaknya selalau berorienrasi pada konsepsi teknologi pendidikan sebagai suatu ilmu yang berdiri sendiri dan selalu mengacu pada landasan falsafah teknologi pendidikan itu sendiri. Untuk itu mata kuliah-mata kuliah yang diberikan dan ditawarkan pada program strata 2 dan 3 UNJ hendak mewajibkan mata kuliah "Landasan Teknologi Pendidikan".

\section{A. PENDAHULUAN}

\section{Latar Belakang}

Perkernbangan IImu Pengetahuan dan Teknologi (IPTEK) dan Globalisasi Informasi, menuntut perlunyapengembangan Sumber Daya Manusia (SDM) yang mampu melanjutkan pembangunan bangsa. Kualitas SDM yang diharapkan adalah yang mampu melaksanakan, mengambangkan dan menciptakan Iptek, sehingga bangsa Indonesia mampu bersaing dengan bangsa-hangsa lain di dunia.

*) Dr. Nurdin Ibrahim, M.Pd., adalah Kepala Bidang Pengembangan Sistem Pustekkom Depdiknas. 
Pengembangan SDM sebagai mana yang di harapkan tersebut merupakan keharusan dan tanggung jawab utama pemerintah melalui Departemen Pendidikan dan kebudayaan (Depdikbud). Pada level pendidikan dasar dan menengah, pemerintah harus rnampu rnenyiapkan dan menghasilkan lulusan yang mampu melaksanakan Iptek baik yang diimpor dari luar maupun yang diciptakan sendiri di Indonesia. Pada level pendidikan tinggi, khususnya strata 2 (S2), harus mampu meyiapkan dan menghasilkan lulusan yang mampu mengembangkan Iptek. Pada Lembaga Pendidikan Tinggi yang menyiapkan tenaga-tenaga dosen dan pendidik untuk level pendidikan tinggi, selain diharapkan mampu mengembangkan Iptek juga harus mampu rnenyiapkan lulusanlulusan yang dapat mentransformasikan IImu dan pengetahuan serta mendidik anak didiknya sebagaimana yang diharapkan Pada starata 3 (S3), harus mampu menyiapkan dan menghasilkan lulusan yang mampu menciptakan dan mengembangkan Iptek melalui berbagai macam penelitian dan pengkajian yang terus menerus sesuai disiplin ilmu yang diembannya.

Untuk mendapatkan dan menghasilkan lulusan-lulusan sebagaima yang diharapkan tersebut di atas, maka masukan (calon mahasiswa) khususnya program teknologi pendidikan harus betul-betul merupakan bibit-unggul yang siap dilatih dan dididik. Selain itu mahasiswa nendaknya mempunyai kemampuan awal yang cukup memadai. Materi tes hendaknya mengukur kemampuan awal siswa, sehingga calon yang diterima betul-betul mempunyai kemampuan awal dengan standar minimal yang diharapkan dan dibutuhkan. Dari uraian tersebut di atas, muncul pentanyaan yang lebih mendasar "apakah mahasiswa S3 program Teknologi Pendidikan telah mempunyai kemampaun awal yang memadai? Kalau belum bagaimana seharusnya bagi siswa S3 teknologi pendidikan yang S2-nya bukan dari program Teknologi Pendidikan? 


\section{B. Landasan Falsafah Teknologi Pendidikan dan Konsepsi Humaniora \\ 1. Falsafah IImu (Pengetahuan)}

Falsafah merupakan sifat dari kata filsafat. Berasal dari bahasa Yunani philosophia dari kata philos atau philem atau philia yang berarti cinta, dan dari kata sophia yang berarti kebijaksanaan atau kearifan at au pengetahuan. Jadi philosophia berarti cinta kepada kebijaksanaan atau kearifan atau pengetahuan. Menurut Dardiri (1986), filsafat dapat dilihat dari dua segi, yaitu dari segi pengetahuan dan aktifitas budi manusia. Dari segi pengetahuan, filsafat adalah jenis pengetahuan yang berusaha mencari hakekat dari segala sesuatu yang ada. Dari segi aktifitas budi manusia, filsafat adalah aktifitas manusia yang secara radikal hendak mencari keterangan yang terdalam tentang sesuatu yang ada. Jadi kalau kita berbicara tentang jenis pengetahuan yang disebut filsafat atau mungkin berarti suatu aktifitas budi manusia dalam mencari keterangan yang terdalam tentang segala sesuatu yang ada.

Seorang yang berfilsafat dapat pula diumpamakan seorang yang berpijak di bumi sedang tengadah ke bintang-bintang. Dia ingin mengetahui hakekat dirinya dalam kemestaan galaksi atau berdiri dipuncak yang tinggi, memandang ke ngarai dan lembah di bawahnya. Menurut Yuyun (1990) bahwa karakteristik berfkir filsafat ada 3 (tiga) yaitu; (a) sifat menyeluruh, (b) sifat mendasar, dan (c) sifat spekulatif.

Sifat menyeluruh beranti seorang ilmuan tidak puas lagi mengenal ilmu hanya dari sudut pandang ilmu itu sendiri. Dia ingin tahu kaitan ilmu dengan moral, kaitan ilmu dengan agama. Dia ingin yakin apakah ilmu itu membawa kebahagiaan atau bermanfaat untuk dirinya. Sifat mendasar berarti seseorang tidak lagi percaya begitu saja bahwa ilmu itu benar. Kalau demikian mengapa disebut benar, apa kriteria penilaian kebenarannya, dan apakah keriteria itu sendiri benar? Filsafat bersifat spekulatif 
karena seseorang untuk mencari kebenaran hanya spekulatif. Spekulatif ini suatu dasar yang tidak bisa diadakan. Namun dalam spekulatif itu yang penting adalah prosesnya, baik dalam analisis maupun pembuktiannya, kita dapat memisahkan spekulasi mana yang dapat diandalkan dan mana yang tidak. Tugas utama filsafat adalah menetapkan dasar-dasar yang dapat diandalkan.

Filsafat adalah menupakan sumber atau induk dari segala ilmu (pengetahuan). Karena itu ada pula istilah filsafat ilmu atau filsafat pengetahuan yang spesifik mengkaji hakekat ilmu (pengetahuan ilmiah). Ilmu itu sendiri merupakan cabang pengetahuan yang mempunyai ciri-ciri tertentu. Secara methodologi ilmu tidak membedakan antara ilmu-ilmu alam dengan ilmu-ilmu sosial. Namun karena permasalahan teknisnya yang bersifat khas maka filsafat ilmu sering dibagi menjadi filsafat ilmu alam dan filsafat ilmu sosial. Pembatasan ini semata-mata untuk pembatasan atau pengkaplian rnasingmasing bidang ditelaah. Selanjutnya Yuyun (1990) menjelaskan bahwa filsafat ilmu merupakan telaahan secara filsafat yang ingin menjawab beberapa pertanyaan mengenai hakekat ilmu itu sendiri. Apa sebagai obyek telaahan ilmu itu? Bagaimana wujud hakiki dari obyek tersebut? Bagaimana hubungan obyek tadi dengan daya tangkap manusia (seperti berfikir rnerasa dan mengindera) yang membuahkan pengetahuan? Pertanyaanpertanyaan tersebut di atas disebut landasan Ontologi.

Bagaimana proses untuk menimba pengetahuan yang berupa ilmu itu? Bagaimana prosedurnya? Hal-hal apa yang harus diperhatikan agar kita mendapatkan pengetahuan yang benar? Apa yang disebut kebenaran dan bagaimana kriterianya? Pertanyaan-pertyanyaan seperti ini disebut landasan Epistimologi.

Untuk apa pengetahuan yang berupa ilmu itu dipergunakan? Bagaimana kaitan antara cara penggunaan tersebut dengan kaidah-kaidah moral? Bagaimana penentuan obyek yang 
ditelaah berdasarkan pilihan moral tersebut? Bagaimana kaitan prosedur yang merupakan operasionalisasi metode ilmiah dengan norma-norma moral profesional? Pertanyaanpertanyaan kelompok ini merupakan landasan aksiologi suatu ilmu.

Dari uraian tersebut di atas maka suatu ilmu dapat berdiri sendiri atau dapat memisahkan diri dari filsafat sebagai induknya, harus jelas landasan ontologinya (mampu menjawab apa garapannya), landasan epistimologi (mampu menjawab bagaimana hakekat dan mengukur kebenarannya), dan landasan aksiologi (mampu menjawab nilai-nilai etis, estetika, nilai kegunaannya untuk kemaslahan manusia, dsb).

\section{Teknologi Pendidikan sebagai IImu}

Teknologi sebagai suatu ilmu yang berdiri sendiri tentu mempun landasan ontologi, epistimologi, dan aksiologi. Selain itu teknologi pendidikan mempunyai obyek material dan formal yang jelas pula.

Landasan ontologi teknologi pendidikan, mempunyai pokok telaahan yang merupakan bagian dari bidang telaahan ilmu pendidikan. Namun timbulnya spesialisasi keilmuan baru justru disebabkan pokok. telaahan telah tidak tergarap, ataupun kalau digarap hanya secara sepintas, jadi tidak mendalam dan cermat. Selain merupakan bagian dari telaahan ilmu pendidikan, teknologi pendidikan juga merupakan bagian telaahan ilmu komunikasi dan psikologi. Setelah ditelaah dari ketiga ilmu tersebut. maka yang belun ditelaah secara mendalam yang kemudian menjadi telaahan dari teknologi pendidikan adalah permasalahan "belajar". Atas dasar landasan ontologinya, maka sebagai obyek material teknologi pendidikan adalah "manusia" sedangkan obyek formalnya adalah "belajar".

Untuk rnembedakan dengan ketiga ilmu sebagaimana disebutkan di atas,obyek materialnya sama yaitu manusia sedangkan obyek formalnya yang berbeda. I I $\quad m \quad u$ 
pendidikan mempunyai obyek formal kepribadian, ilmu komunikasi, kesamaan, dan ilmu psikologi adalah perilaku.

Kedudukan ilmu teknologi pendidikan di antara ilmu komunikasi,

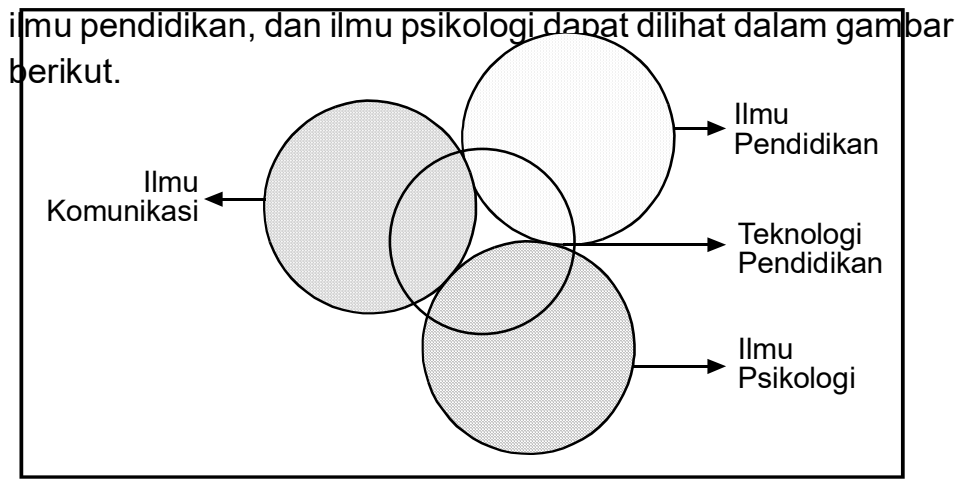

Gambar 1. Hubungan antara

Teknologi Pendidikan dengan IImu lain.

Dari gambar di atas, jelas bahwa untuk memecahkan permasalahan belajar sebagai telaahan utama dari teknologi pendidikan, memerlukan ilmu-ilmu lain terutama ilmu komunikasi, ilmu pendidikan, dan ilmu psikologi. Ilmu pendidikan terutama menelaah masalah (belajar) itu secara keseluruhan tanpa mengkaitkan dengan sudut pandangan ilmu lain, atau memandang masalah (belajar) itu secara terpisah dan berdiri sendiri. Hingga kini ilmu pendidikan umum masih menggunakan pendekatan yang menganggap media audio-visual sebagai alat bantu guru dalam memberikan pelajaran tanpa rnemperhatikan bahwa anak dapat belajar langsung dari media itu tanpa melalui guru. Ilmu komunikasi mempersoalkan media sebagai produk dari disiplin keilmuannya, terutama dalam bentuk perangkat lunak. Ilmu komunikasi tidak mempersoalkan bagaimana media itu dikelola agar terjadi tindakan belajar. Selain tiga ilmu di atas, 
bidang kajian teknologi pendidikan adalah ilmu rekayasa, karena ilmu ini menghasilkan berupa perangkat keras yang berhubungan dengan media. Meskipun produknya itu dirancang untuk kemudian penggunaannya, namun tidak dipersoalkan oleh ilmu rekayasa bagaimana pengelolaannya, pengembangan, dan pemakaian peralatan itu untuk keperluan pendidikan khususnya belajar. masalah-masalah inilah yang kemudian digarap secara tuntas oleh bidang keilmuan baru yang disebut "Teknologi Pendidikan".

Sebagaimana yang telah disebutkan di atas, landasan epistimologi suatu ilmu harus mampu menjawab bagaimana proses yang memungkinkan ditimbanya pengetahuan yang berupa ilmu, bagaimana prosedurnya, hal-hal apa yang perlu diperhatikan, dan beberapa pertanyaan lagi. Ini berarti jawabannya adalah konsepsi atau defenisi dari suatu ilmu itu. AECT bahwa secara konseptual teknologi pendidikan merupakan proses yang kompleks dan terpadu yang melibatkan orang, prosedur, gagasan, peralatan, dan organisasi untuk menganalisis masalah, mencari jalan pemecahannya, melaksanakan, mengevaluasi, dan mengelola pemecahan masalah yang menyangkut semua aspek belajar manusia. Seels dan Richey (1994) mengatakan "Instructional technology is the theory and practice of design, development, utilization, management, and evaluation of processes and resources for learning". Dari kedua definisi tersebut di atas dapat dibuat defenisi teknologi pendidikan sebagai "proses yang komfleks dari merancang, mengembangkan, memanfaatkan, mengelola, dan mengevaluasi yang melibatkan orang, prosedur, gagasan, peralatan, dan organisasi untuk menganalisis masalah, mencari jalan pemecahannya yang menyangkut semua aspek belajar manusia". Dari defenisi tersebut teknologi pendidikan adalah suatu bidang ilmu yang berkepentingan dengan usaha memudahkan proses belajar dengan ciri-ciri khas; (1) memberikan perhatian dan pelayanan khusus kepasa sasaran didik dengan kebutuhan masing-masing; 2) menggunakan 
aneka ragam dan sebanyak mungkin sumber belajar; dan 3) menerapkan pendekatan sistem (System Aproach). Jelaslah bahwa landasan epistimologi teknolog pendidikan adalah memecahkan masalah belajar manusia dengan melalui proses dan pendekatan sistem baik dalam pengembangan, pengelolaan, pemanfaatan, mengevaluasi dengan menempatkan siswa sebagai pusat perhatian.

Sebagai landasan aksiologi suatu ilmu harus mampu menjawab pertanyaan-pertanyaan; Untuk apa ilmu itu dipergunakan?; Bagaimana kaitan antara penggunaan dengan kaidah moral?; Bagaimana penentuan obyek yang ditelaah berdasarkan pilihanpilihan moral?; dsb. Landasan aksiolog teknologi pendidikan adalah dipergunakan untuk memecahkan kesulitan belajar manusia. Banyak manusia karena faktor, sosial, ekonomi, geografis, waktu, dan pekerjaan tidak bisa mengikuti pendidikan yang reguler yang tempat dan waktunya telah ditetapkan secara ketat dan kaku. Secara psikologis masih hanyak manusia baik perkembangan mental dan fisik maupun psikhis tidak mungkin mengikuti sistem persekolahan yang ditangani secara klasikal. Manusia-manusia yang mempunyai berbagai masalah dan kendala inilah yang merupakan garapan dan telaahan utama ilmu teknologi pendidikan dengan menggunakan berbagai macam sumber belajar baik dimanfaatkan secara sendiri-sendiri maupun secara bersama-sama. Dengan kata lain ilmu teknologi pendidikan melayani siswa supaya belajar dengan memperhatikan karakteristik siswa sebagai manusia individu dan sosial.

\section{Humaniora}

Istilah humaniora berasal dari bahasa latin kuno "humanus". Dalam bahasa Inggris searti dengan "the humanities" .yang searti dengan humanus yang berarti manusiawi, berbudaya, dan halus. The humaties berkaitan dengan masalah nilai kita sebagai homo human atau manusia berbudaya (Dardiri, 1986). 
Menurut Elwood yang dikutip oleh L. Wilardjo (Suryasumantri1959) humaniora dapat didefenisikan sebagai seperangkap sikap dan perilaku moral manusia terhadap sesamanya. Ini mengisyaratkan pengakuan terhadap manusia sebagai makluk yang mempunyai kedudukan uni di dalam ekosistem, yang sekaligus juga amat tergantung pada ekosistem itu dan ia sendiri bahkan merupakan bagiannya. Pengertian hubungan sesamanya dapat dikatakan bahwa manusia dalam hidupnya senantiasa berhubungan dengan yang Khalik, dengan sesama manusia, dan alam, baik makhluk yang jasad-jasad hidup maupun benda-benda mati.

Berhubungan dengan yang Khalik, berarti manusia senantiasa berhubungan dengan penciptanya dengan cara-caranya masing-masing sesuai dengan agama yang dianutya. Bersembahyang adalah salah satu contoh cara manusia berhubungan dengan yang Khalik. Berhubungan dengan sesama manusia, berarti kita harus mampu berkomunikasi. Komunikasi itu sendiri berarti ada kesamaan pemahaman terhadap informasi yang disampaikan oleh manusia yang terlibat dalam berkomunikasi. Berbagai ahli komunikasi mengatakan, terjadinya suatu komunikasi yang baika pabila terjadi saling keterbukaan antar komunikator. Dalam kehidupan sehari-hari masih banyak kita jumpai terjadi tidak ada kesepakatan dan kesamaan pendapat, bahkan masih ada yang tidak menghargai karya-karya orang lain berapa pun kecilnya. Dalam hubungan dengan alam lingkungan, masih banyak manusia belum mampu berkomunikasi. Ini ditandai masih banyaknya manusia merusak barang-barang purbakala atau tidak menghargai peninggalanpeninggalan manusia-manusia sebelumnya. Ini berarti kita belum mampu berkomunikasi dengan lingkungan kita sendiri.

Dari uraian di atas, humaniora dapat diartikan sebagai; 1) pengetahuan yang berkaitan dengan nilai-nilai manusia dan ekspresi-ekspresi dari jiwanya; dan 2) seperangkat sikap dan prilaku moral terhadap sesama dan lingkungannya. Ini berarti dengan mempelajari humaniora diharapkan manusia sadar 
bahwa bidang pengetahuan apa saja yang dipelajarinya atau dimilikinya harus berorientasi pada kemanusiaan, untuk kebahagiaan umat manusia dan bukan untuk membawa malapetaka.

\section{Program Strata 3 Teknologi Pendidikan IKIP Jakarta}

Di atas telah diuraikan bahwa obyek formal ilmu teknologi pendidikan adalah "belajar" dan obyek materialnya adalah "manusia". Begitu pula teknologi pendidikan sebagai suatu ilmu yang berdiri sendiri, landasan aksiologinya senantiasa mengandung nilainilai etika, moral, dan budaya sesuai dengan konsepsi keilmuan dalam teknologi pendidikan. Begitu pula berdasarkan konsepsi humaniora, orang-orang yang mempunyai keahlian dalam bidang teknologi pendidikan harus berorientasi pada kemanusiaan yaitu mengupayakan orang-orang yang tidak bisa belajar karena berbagai faktor harus bisa belajar, tanpa harus mempehutungkan perbedaan ras, suku, agama, dan status sosial. Di samping itu, ahli teknologi pendidikan harus dapat berupaya supaya sasaran didiknya merasa dihargai sesuai dengan perbedaan-perbedaan berdasarkan karakteristik sebagai manusia individu dan sosial. Program pascasarjana IKIP Jakarta sebagai lembaga pendidikan tinggi, juga haris berupaya menghasilkan lulusannya yang mempunyai keahlian dalam bidangnya, (fungsi pendidikan), mampu melaksanakan penelitian sebagai upaya mengembangkan ilmunya (fungsi penelitian), dan mampu mengaplikasikan ilmunya di masyarakat (fungsi pengabdian masyarakat). Oleh karena itu program sarjana IKIP Jakarta senantiasa menyiapkan lulusannya khususnya program strata 3 , di samping mampu mengemban fungsi-fungsi Tridarma Perguruan Tinggi, juga mampu mengaplikasikan dan mengembangkan keahliannya sesuai dengan konsepsi keteknologipendidikan, serta mengacu pada konsepsi kehumanioraan dan landasan aksiologi ilmunya. Oleh karena itu, program-program atau mata kuliah-mata kuliah yang ditawarkan dan harus ditempuh oleh mahasiswa strata 2 dan 3 teknologi pendidikan harus mengacu kepada berbagai landasan dan konsepsi tersebut itu. 
Untuk mencapai sebagaimana yang diharapkan tersebut di atas, menur ut hemat penulis mata kuliah-mata kuliah yang yang harus ditawarkan atau ditempuh oleh mahasiswa strata 2 atau strata 3 program teknologi pendidikan adalah sebagai berikut.

\section{Mata Kuliah Umum}

a. Filsafat ilmu dan berfikir kesistiman; Mata kuliah ini untuk membekali mahasiswa sebagai calon peneliti dan mampu meneliti baik secara mandiri dan kelompok.

b. Pengembangan tes dan instrumen penelitian; Mata kuliah ini sebagai bekal untuk menunjang mata kuliah yang pertama yaitu mampu melaksanakau penelitian mandiri terutama menyelesaikan Disertasinya. Bila memungkinkan juga dapat mengajarkan ilmu tersebut apabila kembali ke lembaga pendidikan asalnya.

c. Psikologi pendidikan; Mata kuliah ini akan menunjang obyek material (manusia) semua disiplin ilmu yang isinya diharapkan mengkaji perkembangan manusia, kepribadian (termasuk di dalamnya nilai moral, sosial dan budaya), intelegensi dan keberbakatan, serta kecenderungankecenderungan pengaplikasian di masa mendatang.

d. Penilaian proses dan hasil belajar; Mata kuliah ini berguna untuk menopang para lulusan dalam mengevaluasi keberhasilan belajar mahasiswanya terhadap mata kuliah yang bersangkutan. Mata kuliah ini secara garis pengertian penilaian (evaluasi), perbedaan penilaian dan pengukuran, teknik dan prosedur penilaian, teknik dan prosedur pengembangan tes, dan kriteria keberhasilan berdasarkan acuan norma dan acuan patokan, serta teknik menghitung nilai perolehan berdasarkan nilai mentah.

\section{Mata Kuliah Wajib}

Untuk menunjang mahasiswa mendalami keahlian dalam teknologi pendidikan, menurut hemat penulis mata kuliah-mata kuliah wajib bagi mahasiswa strata 3 teknologi pendidikan adalah 
sebagai berikut.

a. Landasan teknologi pendidikan; Mata kuliah ini merupakan mata kuliah utama bagi mahasiswa strata 3 dan strata 2 program teknologi pendidikan. Mata kuliah ini akan menunjang mahasiswa yang merasa diri keahliannya dalam teknologi pendidikan. Garis besar isinya antara lain harus memuat; landasan falsafah teknologi pendidikan, sejarah perkembangan paragigma teknologi pendidikan, definisi dan konsepsi teknologi pendidikan sebagai bidang dan profesi, serta ilmu lain yang menunjang.

b. Psikologi belajar; Mata kulian ini diberikan sebagai upaya untuk memperkuat dan menunjang mahasiswa dalam mendalami aspek-aspek belajar manusia. Garis besar isinya hendaknya memuat hakekat perkembangan manusia termasuk kepribadiannya, hakekat perkembangan manusia dari pra sekolah, masa sekolah, mahasiswa, pendidikan orang dewasa dan luar sekolah. Diharapkan juga dibahas tentang motivasi berprestasi dan/atau motivasi belajar, diagnostik kesulitan belajar, serta usaha-usaha untuk meningkatkan motivasi dalam belajar. Jelasnya mata kuliah ini menunjang keterlaksanaan obyek formal teknologi pendidikan sebagai ilmu yang berdiri sendiri.

c. Pengembangan dan produksi media belajar; Mata kuliah ini sangat penting dan diupayakan dapat didalami oleh mahasiswa. Media belajar adalah salah satu komponen dalam proses pembelajaran yang cukup dapat memberikan andil untuk keberhasilan belajar sasaran didik. Dalam mata kuliah ini, mahasiswa disamping mendalami berbagai macam dan jenis media, hakekat media, langkah-langkah pengembangan dan produksi, langkah-langkah dan teknik mengevaluasi media, serta teknik pemanfaatannya dalam proses pembelajaran.

d. Disain instruksional; mata kuliah ini sangat menunjang mahasiswa setelah lulus kelak dapat merancang pembelajaran yang efektif, menarik, dan memungkinkan 
peningkatan hasil belajar mahasiswanya. Mata kuliah hendaknya berisi teknik, prosedur, dan langkah-langkah pengembangan dan merancang instruksional. Juga mengandung berbagai model pengembangan dan disain instruksional.

e. Psikologi komunikasi dalam pendidikan; Mata kuliah ini sangat bermanfaat untuk mendalami hakekat komunikasi manusia antara manusia, manusia dengan kelompok (massa), komunikasi langsung dan tidak langsung antar personal, medium yang efektif dalam berbagai macam komunikasi, dan komunikasi yang memungkinkan terjadinya interaksi dalam pendidikan.

f. Kawasan penelitian teknologi pendidikan;Mata kuliah ini sangat bermamfaat untuk menunjang mahasiswa dalam mendalami penelitian, baik penelitian disertasi maupun penelitian untuk menopang fungsi Tridarma Perguruan Tinggi setelah mahasiswa kembali ke Perguruan Tinggi masing-masing. Mata kuliah ini juga dapat mengklasifikasi bidang-bidang yang dapat diteliti dalam teknologi pendidikan, macam-macam penelitian yang dapat dikategorikan dalam kawasan teknologi pendidikan dan bukan, serta berbagai hasil atau temuan penelitian bidang teknologi pendidikan yang dilaksanakan di negara-negara maju dan berkembang.

g. Difusi inovasi pendidikan; Teknologi pendidikan adalah merupakan bagian dari ilmu pendidikan umum yang relatif masih baru. Bahkan di Indonesia masih dirasakan baru. Oleh karena itu, ilmu teknologi pendidikan masih perlu didifusikan secara meluas dan memasyarakat. Untuk itu mahasiswa teknologi pendidikan harus tau bagaimana prosedur, langkah-langkah, dan kiat-kiat untuk mendifusikan teknologi pendidikan di lembaga-lembaga pendidikan. Selain itu melalui mata kuliah ini mahasiswa diharapkan mampu menyeharkan, mendifusikan segala sesuatu yang baru dalam kawasan ilmunya maupun kawasan pendidikan pada umumnya. Garis besar isi mata kuliah ini, di antaranya 
harus mengandung konsepsi keinovasian, elemen-elemen difusi, atribut inovasi dau percepatan difusi, proses keputusan dalam inovasi, jaringan difusi, inovasi dan organisasi, konsekuensi inovasi, dan sebagainya.

\section{Kajian}

Mata kulialh-mata kuliah yang perlu ditawarkan pula untuk program teknologi pendidikan antara lain; mata kuliah humaniora;. evaluasi kurikulum, psikologi sosial dalam pendidikan, pengelolaan organisasi personil dalam pendidikan pengelolaan pusat sumber belajar, pengembangan pendidikan dan pelatihan, pengelolaan pendidikan jarak jauh dan pendidikan terbuka; dan pendidikan terbuka.

Namun kenyataannya di program pasca sarjana IKIP Jakarta, khususnya mahasiswa strata 3 yang mempunyai ijazah strata 2-nya bukan dari teknologi pendidikan seakan-akan tidak diharuskan untuk mengambil mata kuliah "Landasan Teknologi Pendidikan". Padahal mata kuliah ini merupakan mata kuliah yang dapat membuka pikiran, perasaan, dan pengetahuan mahasiswa tentak teknologi pendidikan, apa obyek formal dan materialnya, apa landasan ontologi, epistimologi, dan aksiologi teknologi pendidikan. Akibatnya banyak mahasiswa yang bersangkutan pengertian belajar saja, apalagi yang berbau kefilsafatan teknologi pendidikan, dan apa saja bidang garapannya. Banyak terjadi pertentangan antara mahasiswa teknologi pendidikan berkaitan dengan hal-hal yang sepele, seperti apakah metodelogi pendidikan, alat peraga dalam pendidikan masuk dalam bahasan teknologi pendidikan. Tentu saja mahasiswa yang tidak pernah mempelajari atau belum memperoleh mata kuliah teknologi pendidikan, pengembangan dan produksi media akan mempertahankan kedua istilah yang dipertentangkan tersebut di atas mati-matian. Padahal dalam konsep teknologi pendidikan sebagaimana yang telah disebutkan di atas, tidak mengenal istilah alat bantu mengajar seperti istilah dalam pendidikan umum, tetapi yang dikenal 
adalah media belajar atau sumber belajar. Teknologi pendidikan tekanannya adalah bagaimana siswa belajar bukan bagaimana guru mengajar.

Karena fungsi guru sebagai transmisi pengetahuan sudah ditinggalkan. Fungsi guru lebih kepada transformasi pengetahuan, sebagai pengelola belajar, motivator, evaluator, tutor, pemecah kesulitan belajar.

Di sisi lain, masih banyak mahasiswa yang belum tahu bidangbidang garapan teknologi pendidikan, sehingga banyak di antara mahasiswa dalam mengajukan judul tesis dan disertasinya tidak mengacu pada konsepsi teknologi pendidikan. Begitu pula lulusan-lulusan teknologi pendidikan strata 2 dan strata 3 dalam menjalankan tugasnya malah tidak mencerminkan sebagai lulusan teknologi pendidikan. Misalnya, banyak sekali mereka tidak berusaha bagaimana supaya materi yang diajarkannya mudah dimengerti oleh mahasiswanya sehingga mahasiswa betul-betul belajar, pengetahuan, keterampilan, dan sikapnya berubah dan belum tau menjadi tau. Mereka yang mengalami kesulitan belajar karena faktor-faktor di luar dirinya dapat dipecahkan sehingga mudah memperoleh kesempatan belajar. Mereka (lulusan teknologi pendidikan) nampaknya acuh dan tidak mau berusaha sebagaimana yang diharapkan oleh konsepsi keilmuannya. Padahal contoh-contoh tersebut di atas, merupakan landasan aksiologi teknologi pendidikan dan sekaligus merupakan harapan dari manusia-manusia yang humanioralis. Tidak ada nilai moral dan nilai etis yang tinggi dari lulusan teknologi pendidikan kecuali membantu mianusiamanusia karena berbagai faktor tidak bisa belajar dengan baik atau tidak bisa belajar ke jenjang yang lebih tinggi. Tidak ada nilai moral dan etis yang tinggi dari lulusan teknologi pendidikan apabila tidak mampu memecahkan gap antara, manusia golongan atas dan bawah yang diakibatkan oleh tidak berkesempatan belajar. Nilai-nilai moral dan etis inilah yang ditakutkan oleh penulis terhadap para lulusan program teknologi 
pendidikap strata 3 yang tidak pernah memperoleh bimbingan dan tempaan melalui mata kuliah landasan teknologi pendidikan. Miarso (1993) mengatakan, program studi dengan pertimbangan non-profesional.; mengakibatkan a) Kurikulum dan program dikembangkan dengan orientasi yang tidak tepat. Hampir semua kurikulumnya dirancang untuk menghasilkan guru. b) kinerja para lulusannya di bawah standar harapan calon pemakainya;

c) kurang besarnya idealisme dan tekad mereka yang mempunyai keahlian untuk menunjukkan identitas keahliannya dalam membantu memecahkan masalah pendidikan dan pembelajaran mau mengorbankannya demi sesuap nasi.

\section{Kesimpulan dan Saran \\ 1. Kesimpulan}

Dari uraian tersebut di atas, maka dapat diambil suatu kesimpulan bahwa

a. Mata kuliah yang ditawarkan kepada mahasiswa program strata 3 teknologi pendidikan bagi mahasiswa yang berijazah strata 2 non teknologi pendidikan belum dikelola sebagaimana yang diharapkan.

b. Khusus mata kuliah landasan teknologi pendidikan sebagai mata kuliah utama untuk membentuk keteknologipendidikan mahasiswanya belum diberikan secara menyeluruh terutama bagi mahasiswa strata 3 yang berasal dari strata 2 non teknologi pendidikan.

\section{Saran-saran}

a. Untuk membentuk keahlian dalam keteknologi-pendidikan mahasiswa strata 3, mata kuliah-mata kuliah yang ditawarkan perlu dikelola dan ditinjau kembali terutama bagi mahasiswa yang berasal dari strata 2 non teknologi pendidikan. 
b. Mata kuliah landasan teknologi pendidikan, hendaknya diupayakan untuk diwajikan ditempuh oleh semua mahasiswa strata 2 dan 3 teknologi pendidikan. Oleh karena itu mahasiswa strata 3 teknologi pendidikan yang berasal dari strata 2 non teknologi pendidikan diwajibkan menempuh mata kuliah landasan teknologi pendidikan.

\section{DAFTAR KEPUSTAKAAN}

Dardiri, H.A., 1985, Humaniora, Filsafat, dan Logika, PT. RajawaliJakarta.

Huijbers, Theo, 1986, Manusia Merenungkan Dirinya, KanisiusJakarta.

Miarso, Yusufhadi, 1989, Teknologi Pendidikan, Monograf, PAU-UT, Dirjen Pendidikan Tinggi.

, 1994, Prospek Teknologi Pendidikan di Masa Depan, Ikatan Profesi Teknologi Pendidikan Indonesia, Jakarta.

Plomp, Tjeerd dan Ely, Donald P., (editor', 1996, International Encyclopedia of Education Technology, second edition. Pergamon; Cambridge University, Press.

Seel, Barbara B end Richey, 1994, Instructional TechnologyDefinition and Domains of the Field, AECT, Washington DC.

Suryasumantri, Yuyun S.,1990, Filsafat IImu Sebuah Pengantar Populer, Pustaka Sinar- Harapan, Jakarta.

_ , 1991, IImu Dalam Perspektif, Sebuah Kumpulan Karangan Tentang Hakekat IImu, Yayasan Obor, Indonesia..

Verhaak, C., dan Imam, R. Haryono, 1989, Filsafat IImu Pengetahuan, PT. Gramedia-Jakarta. 